\title{
A Comparison across Ranks of Well-being among Police Officers in Malaysia
}

\author{
Yassin, Sulaiman ${ }^{1}$, Adriana Ortega ${ }^{1}$, Jeffrey Lawrence D'Silva ${ }^{1}$, Asnarulkhadi Abu Samah ${ }^{1} \&$ Siti Zobidah Omar $^{1}$ \\ ${ }^{1}$ Institute for Social Science Studies, Universiti Putra Malaysia, Malaysia \\ Correspondence: Adriana Ortega. Institute for Social Science Studies, Putra Infoport, Universiti Putra Malaysia, \\ 43400 Serdang, Selangor, Malaysia. Tel: 603-8947-1897. E-mail: adryortearo@gmail.com
}

Received: August 12, 2014 Accepted: September 2, 2015 Online Published: December 21, 2015

doi:10.5539/ass.v12n1p151 URL: http://dx.doi.org/10.5539/ass.v12n1p151

\begin{abstract}
Objective: This paper aimed to determine the level of well-being of Police officers and to assess and compare the well-being levels among police officers of low, middle and high ranks. Methods: Data were obtained using a context specific questionnaire that was distributed across the five geographic zones of Malaysia. Results: The results indicate that overall police officers' well-being is in need of improvement. Low rank officers faced poor work environment, deficient financial security and economic well-being, lack of opportunity for continuing education and career, poor overall physical health and negative political and spiritual well-being. The finding of this study provides the necessary information to develop and implement measures to enhance the current well-being of police officers.
\end{abstract}

Keywords: objective well-being, subjective well-being, police officer

\section{Introduction}

Well-being is a holistic concept in which individuals are understood as biopsychosocial beings and their welfare centers on the efficiency of their body, mind, and spirit (Bowling 1997). Well-being is conceptualized as 'feeling good and functioning well' (Sen, 1982); and it comprises people's experience of their life and a comparison of life circumstances with social norms and values. It can be assessed in terms of two major dimensions, the Objective and Subjective dimensions (Campbell, Converse, \& Rodgers, 1976). The objective dimension of well-being might include socio-economic indicators (Diener \& Suh, 1997), while the subjective dimension comprises individual's cognitive evaluation of their (a) life satisfaction, (b) sense of happiness (c) level of anxiety and pessimism, etc. (Veenhoven, 2007; Diener 1995).

Generally objective well-being refers to a list of requirements that need to be fulfilled in order for people to have 'a good life'. These requirements are based on the normative Theory of Human Need (Doyal \& Gough, 1991) and are assumed to be universal and static regardless the contextual and cultural background of societies and/or organizations. Thus measures of objective well-being include a list of indicators of for example availability and type of housing, socioeconomic status, net income, financial security, education level, physical and mental health symptomatology (Lucas, Diener, \& Suh, 1996). On the other hand, subjective well-being refers to how individuals appraise their own satisfaction with life as a whole (Cummins, 1997; Diener, 2009; Rees, Bradshaw, Goswami, \& Keung, 2010; Rees et al., 2012). Thus, subjective well-being is the individuals' multidimensional evaluation of their lives; that includes both cognitive judgments of life satisfaction and affective evaluations of moods and emotions (Eid \& Diener 2003). Therefore, measures of subjective well-being consist of self-reported thoughts and feelings about various aspects of life such as life satisfaction, happiness, work, relationships, as well as the individuals' assessment of their emotions, happiness, and meaningfulness of life in reference to discrete life domains like home life, friendships, work, school, material wealth, etc. (Lucas, Diener, \& Suh, 1996; Diener, 2009).

In developing societies it is only recently that the notion of well-being has become of interest both in academic research and policy-oriented analysis. In Malaysia, there are very few studies that have focused on well-being (Noor, Gandhi, Ishak, \& Wok, 2014; Hussin, 2014; Mokhtar et al., 2015; Yassin et al., 2015). One of those studies was conducted by Noor and colleagues (2014) it focused on family well-being in Malaysia (Noor, Gandhi, Ishak, \& Wok, 2014). Wok (2014) and developing a family well-being index using five dimensions: family relationships, economic situation, health and safety, community relationship and religion or spirituality. 
The findings from Noor and colleagues' (2014) study indicated that in Malaysia family well-being was relatively high at 7.95 (the scale ranged from on a 0-10 scale); and the findings reported by Hussin (2014) showed that high work-family conflict was significant associated with negative well-being among working Malaysian women. Mokhtar and colleagues (2015) examined financial well-being among public employees in Malaysia and their results indicated that overall, public sector employees in Malaysia had moderate levels of well-being. The most recent study on well-being in Malaysia was conducted by Yassin. S. M. and colleagues (2015); they examined the objective and subjective dimensions of well-being. Their study results showed that sociodemographic factor (e.g. geographic location, age, income, and gender) and work-life balance are important determinants of the well-being.

The police force in Malaysia is interested in addressing the factors that impact negatively officer's well-being. Therefore the research team at the Institute for Social Science at UPM was commissioned to assess the level of Well-being of police personnel across Malaysia. Working for the police has been described as highly hazardous occupation in the literature on occupational health and occupational stress (He, Zhao, \& Archbold, 2002, Anshel, 2000). Police officers deal with violent, antisocial and untrustworthy individuals of society, and as a law enforcement occupation, police personnel are expected to employ discretion under difficult and often critical circumstances and remain detached from their emotions. In addition, police officers face increasing demands on police personnel from politicians and members of the public and perform their work tasks despite the lack of resource and understaffing. Therefore, uniformed personnel are at high work related risks which can have negative impact on their well-being and as result their engagement and job outcomes might be in jeopardy (Wright et al., 2006; Hoque et al., 2004). Furthermore, poor well-being among police officers is associated with either early retirement and/or poor quality of life after retirement (Anshel, 2000). The long-term effects of diminished well-being of police personnel not only increases their risk of individual health problems, but it also can increase the organizational loses in terms of health care cost, absenteeism, understaffing, poor personnel retention, and potential risks of disgruntled employees (Cartwright \& Cooper, 2014; Sparks, Faragher, \& Cooper, 2001).

The present study aimed to assess and compare the level of well-being of Police officers. More specifically the objectives of this study were to (a) assess the Objective and Subjective well-being of police officers and (b) compare police officers' objective and subjective well-being based on their rank.

\section{Method}

The data used in this paper was obtained from a larger cross-sectional study carried out to assess the overall well-being of police officers in Malaysia. Data was obtained using a context specific questionnaire that was distributed across the five geographic zones of Malaysia. Prior to data collection the questionnaire's validity and reliability were assessed through a pilot study, the scale validity and reliability were evaluated using Cronbach Alpha (Table 1).

\subsection{Sample}

The sample consisted of 1201 serving police officers from all 5 geographical regions of Malaysia. The mean age of the participants was 42.08 (11.03) years old, the average time in service as officers was 20.76 (11.72) years; and $82.5 \%$ of the sample were male police officer (Table 2 ).

\subsection{Measurements}

For the purpose of this study, the dimensions of police well-being used were the following

1. Objective Well-being (OWB) measures consisted of officers' monthly income in Malaysian Ringgits, financial well-being and life style:

- Financial well-being was measured in terms of officers' monthly expenses, savings and housing.

- Lifestyle consisted of officer's fitness level, number of medical checkup per year; body mass index (BMI), number of cigarettes smoked daily, number of alcoholic beverages consumed daily, and number of hours of sleep daily.

2. Subjective Well-being (SWB), comprised the following subjective measures

- Communication well-being: officer's perception and satisfaction with the overall communication process at individual and organizational level

- Economic well-being officer's satisfaction with the remuneration, financial benefits and incentives they received 
- Employee well-being: officer's perception of their work related demands and tasks

- Environmental well-being: officers' satisfaction with availability of green areas and natural resources; level of water and noise pollution, and management of garbage and waste disposal in their place of residence

- Education well-being: officers' perception of and satisfaction with the available continuing education and career development opportunities

- General physical well-being : overall satisfaction of officers with their physical working condition

- Political well-being : officer's satisfaction with the government and its politics

- Public safety: officers' perception of their family safety in their residential areas

- Social well-being : officers' perception of and satisfaction with their interpersonal relationship at work and in their community

- Spiritual Well-Being: officers' level of self-awareness and personal identity.

All items in the subjective measurements were assessed using a 5-likert scale ranging from Strongly Disagree. High scores indicate positive well-being and low scores indicate negative well-being. Their reliability and validity were assed using Cronbach Alpha coefficient; the results from the validity and reliability test are summarized in Table 1.

\subsection{Analysis}

The assessment and comparison of well-being among police officers were carried out using IBM SPSS Statistics package 21.0. Frequency analysis and One-Way Anova were used to assess the differences across rank in terms of objective and subjective well-being.

\section{Results}

Table 1 surmises the reliability and validity test for subjective measurements of well-being; and Table 2 contains the sociodemographic characteristics of the participants.

Table 1. Reliability and validity test for subjective measurements of well-being

\begin{tabular}{ccc}
\hline Subjective Well-being dimensions & No of Items & Cronbach Alpha coefficient \\
\hline Communication well-being & 7 & .890 \\
Economic well-being & 6 & .866 \\
Education well-being & 6 & .727 \\
Employee well-being & 11 & .908 \\
Environmental well-being & 7 & .745 \\
Political well-being & 7 & .876 \\
General physical well-being & 7 & .815 \\
Social well-being & 11 & .932 \\
Spiritual Well-Being & 7 & .920 \\
Public safety & 5 & .660 \\
\hline
\end{tabular}

For the purpose of this study, participants were grouped into 3 categories according to their rank; these categories were Low, Middle and High rank officers. Low rank consisted of Lance Corporal; Constable and Corporal police officers; Middle rank included Sergeant, Sergeant Major and Sub Inspector; High Rank consisted of, Inspector, ASP, DSP and Superintendent

Table 2 , shows that $64.2 \%$ of the sample had completed secondary education, and only $5.3 \%$ completed tertiary education. Overall more than half of the participants (59.7\%) were low rank or subordinated officers; and 37.2\% of the total sample have a monthly income below RM 1,500.00 (about USD 381.64) in other words they do not earn enough to make ends meet.

The frequency analysis, presented on Table 3, indicated that the overall well-being mean score among police 
officers was 34.69 (4.41). According to the results of the Analysis of variance there was a significant difference in terms of rank in officers' overall score in well-being $[\mathrm{F}(2)=62.51$; C.I. $=34.44-34.94 ; \mathrm{p}<0.001]$. The post-hoc analysis indicate that officers of lower rank sored significantly lower that middle and high rank officers $(p<0.05)$.

Table 2. Socio demographic characteristic of the sample

\begin{tabular}{|c|c|c|}
\hline & $\mathrm{n}$ & $\%$ \\
\hline \multicolumn{3}{|l|}{ Age Group } \\
\hline Under 30 & 260 & 21.6 \\
\hline $31-40$ & 308 & 25.6 \\
\hline $41-50$ & 242 & 20.1 \\
\hline $51-60$ & 391 & 32.6 \\
\hline \multicolumn{3}{|l|}{ Gender } \\
\hline Male & 991 & 82.5 \\
\hline Female & 210 & 17.5 \\
\hline \multicolumn{3}{|l|}{ Education } \\
\hline Primary education (PMR/SRP/LCE) & 145 & 12.1 \\
\hline Secondary education (SPM / MCE / PMV) & 771 & 64.2 \\
\hline Certificate of Proficiency / Vocational / Technical & 37 & 3.1 \\
\hline Post-secondary education (STPM / Diploma) & 184 & 15.3 \\
\hline Tertiary education (Bachelor degree/ Master / PhD) & 64 & 5.3 \\
\hline \multicolumn{3}{|l|}{ Rank } \\
\hline Low Rank officers & 716 & 59.71 \\
\hline Middle Rank officers & 360 & 30.03 \\
\hline High Rank officers & 123 & 10.26 \\
\hline \multicolumn{3}{|l|}{ Years of Service } \\
\hline Less than 5 years of service & 129 & 10.7 \\
\hline 6-10 years of service & 203 & 16.9 \\
\hline $11-20$ years of service & 278 & 23.1 \\
\hline $21-30$ years of service & 226 & 18.8 \\
\hline 31 or more years of service & 365 & 30.4 \\
\hline \multicolumn{3}{|l|}{ Net monthly Income } \\
\hline$<\mathrm{RM} 1,500$ & 447 & 37.2 \\
\hline RM1,501-RM3,000 & 379 & 31.6 \\
\hline RM3,001-RM4500 & 214 & 17.8 \\
\hline RM4,501-RM6,000 & 94 & 7.8 \\
\hline$>$ RM6,000 & 67 & 5.6 \\
\hline
\end{tabular}

Furthermore in terms of objective well-being $[\mathrm{F}(2)=60.79 ;$ C.I. $=30.84-31.33 ; \mathrm{p}<0.001]$ and subjective well-being $[\mathrm{F}(2)=15.89$; C.I. $=50.17-50.71 ; \mathrm{p}<0.001]$ similar differences were observed (Table 3). Low rank officers exhibited lower levels of objective well-being and subjective well-being that middle and higher rank officers $(\mathrm{p}<0.05)$. Interestingly, middle rank officers reported significantly higher levels of subjective well-being in comparison to higher rank officers $(\mathrm{p}<0.05)$. 
Table 3. Objective and subjective well-being by rank

\begin{tabular}{|c|c|c|c|c|c|c|}
\hline & & \multirow{2}{*}{$\mathrm{N}$} & \multirow{2}{*}{ Mean } & \multirow{2}{*}{ Std. Deviation } & \multicolumn{2}{|c|}{ 95\% Confidence Interval } \\
\hline & & & & & Lower Bound & Upper Bound \\
\hline \multirow{3}{*}{ Overall well-being } & Low Rank Officers & 716 & 33.65 & 4.32 & 33.34 & 33.97 \\
\hline & Middle Rank Officers & 360 & 35.75 & 3.99 & 35.33 & 36.16 \\
\hline & High Rank Officers & 125 & 37.57 & 4.15 & 36.84 & 38.31 \\
\hline \multirow{3}{*}{$\begin{array}{c}\text { Objective } \\
\text { well-being }\end{array}$} & Low Rank Officers & 716 & 30.10 & 4.24 & 29.78 & 30.41 \\
\hline & Middle Rank Officers & 360 & 32.07 & 3.90 & 31.66 & 32.47 \\
\hline & High Rank Officers & 125 & 33.94 & 4.02 & 30.84 & 31.33 \\
\hline \multirow{3}{*}{$\begin{array}{l}\text { Subjective } \\
\text { well-being }\end{array}$} & Low Rank Officers & 716 & 49.82 & 4.76 & 49.4716 & 50.1706 \\
\hline & Middle Rank Officers & 360 & 51.50 & 4.58 & 51.03 & 51.98 \\
\hline & High Rank Officers & 125 & 50.92 & 4.86 & 50.06 & 51.78 \\
\hline
\end{tabular}

\subsection{Objective Well-being}

In terms of objective well-being, officers reported low scores in house ownership, lifestyle, and financial well-being. The frequency analysis results showed that a significant proportion of officers (31\%) do not own a house (Table 4). More specifically among the officers who reported that they do not own a home, $44.6 \%$ of the lower rank officers; $8.3 \%$ of the middle rank and $18.4 \%$ of the higher rank officers currently do not have house ownership $\left[\chi^{2}(2)=157.31 ; p<0.001\right]$.

Table 4. Housing by rank

\begin{tabular}{ccc}
\hline Rank & \multicolumn{2}{c}{ Do you own a house? } \\
\cline { 2 - 3 } & Yes & No \\
\hline Low Rank Officers & $397(55.4 \%)$ & $319(44.6 \%)$ \\
Middle Rank Officers & $330(91.7 \%)$ & $23(18.4 \%)$ \\
High Rank Officers & $102(81.6 \%)$ & $372(31 \%)$ \\
Total & $829(69 \%)$ & \\
\hline
\end{tabular}

$\overline{\chi^{2}(2)=157.31 ; p<0.001}$

The analysis of variance results also showed significant differences among police officers in terms of their Lifestyle $[\mathrm{F}(2)=4.75 ;$ C.I. $=22.27-22.66 ; \mathrm{p}=0.009]$; Income $[\mathrm{F}(2)=61.58 ; \mathrm{CI}=2279.88-2495.08 ; \mathrm{p}<0.001]$ and Financial Safety $[\mathrm{F}(2)=25.01 ;$ C.I. $=11328.27-14471.14 ;$ p0.001] $($ Table 5).

Furthermore, the post-hoc test results indicated that middle rank officers (e.g. Sergeant and Sub Inspectors) exhibited healthier life style that both higher and lower rank officers $(\mathrm{p}<0.05)$. On the other hand, high rank officers (e.g. Inspectors, Superintendents) had better income and financial security than both middle and lower rank officers $(\mathrm{p}<0.05)$.

Table 5. Objective well-being dimensions by rank

\begin{tabular}{|c|c|c|c|c|c|c|}
\hline & & \multirow{2}{*}{$N$} & \multirow{2}{*}{ Mean } & \multirow{2}{*}{ Std. Deviation } & \multicolumn{2}{|c|}{ 95\% Confidence Interval } \\
\hline & & & & & Lower Bound & Upper Bound \\
\hline \multirow{3}{*}{ Lifestyle } & Low Rank Officers & 716 & 22.34 & 3.49 & 22.08 & 22.59 \\
\hline & Middle Rank Officers & 360 & 22.89 & 3.23 & 22.56 & 23.23 \\
\hline & High Rank Officers & 125 & 21.98 & 3.15 & 21.42 & 22.53 \\
\hline \multirow{3}{*}{ Income } & Low Rank Officers & 716 & 1923.09 & 1538.04 & 1810.25 & 2035.94 \\
\hline & Middle Rank Officers & 360 & 2948.21 & 2117.40 & 2728.74 & 3167.67 \\
\hline & High Rank Officers & 125 & 3432.57 & 2254.07 & 3033.53 & 3831.61 \\
\hline \multirow{3}{*}{$\begin{array}{c}\text { Financial } \\
\text { Safety }\end{array}$} & Low Rank Officers & 716 & 9116.18 & 20515.69 & 7610.91 & 10621.45 \\
\hline & Middle Rank Officers & 360 & 15594.59 & 31917.33 & 12286.41 & 18902.78 \\
\hline & High Rank Officers & 125 & 26810.45 & 42204.60 & 19338.88 & 34282.02 \\
\hline
\end{tabular}




\subsection{Subjective Well-being}

In terms of subjective well-being office there were significant differences based on rank in environmental well-being [F (2) =4.04; C.I. =3.34-3.42; $\mathrm{p}=.02]$; employee well-being $[\mathrm{F}(2)=10.12$; C.I. $=2.72-2.80 ; \mathrm{p}<.001]$; spiritual well-being $[\mathrm{F}(2)=6.06$; C.I. $=3.37-3.64 ; \mathrm{p}=.002]$; education well-being $[\mathrm{F}(2)=14.07$; C.I. $=3.47-3.53$; $\mathrm{p}<.001]$; political well-being $[\mathrm{F}(2)=9.80$; C.I. $=3.59-3.67$; $\mathrm{p}<.001]$; general physical well-being $[\mathrm{F}(2)=8.00$; C.I. $=3.78-3.84 ; \mathrm{p}<.001]$; economic well-being $[\mathrm{F}(2)=23.73$; C.I. $=3.28-3.36 ; \mathrm{p}<.001]$; and public safety $[\mathrm{F}(2)=$ 14.96; C.I. $=3.35-3.42 ; \mathrm{p}<.001]$ (Table 6). The post hoc analysis indicated that lower rank officers were less satisfied with public safety $(\mathrm{p}<0.5)$ at their place of residence; and had less access to continuing education and career development opportunities $(\mathrm{p}<0.05)$ in comparison to middle and high rank officers.

On the other hand, middle rank officers scored more positively than lower rank officer $(p<0.05)$ in spiritual well-being. Also middle rank officers exhibited higher employee well-being $(\mathrm{p}<0.05)$, positive political well-being $(p<0.05)$ and social well-being $(p<0.05)$ than their lower and higher rank colleagues $(p<0.05)$. Higher rank officers exhibited better physical health $(\mathrm{p}<0.05)$ and economic well-being $(\mathrm{p}<0.05)$, than both middle and lower rank officers $(\mathrm{p}<0.05)$. The post hoc analysis indicated that lower rank officers were less satisfied with the physical environmental $(p<0.05)$ surrounding their work and home and with public safety $(p<0.5)$ at their place of residence; and had less access to continuing education and career development opportunities $(p<0.05)$ in comparison to middle and high rank officers.

Table 6. Subjective well-being by rank

\begin{tabular}{|c|c|c|c|c|c|c|}
\hline & & \multirow{2}{*}{$N$} & \multirow{2}{*}{ Mean } & \multirow{2}{*}{ Std. Deviation } & \multicolumn{2}{|c|}{ 95\% Confidence Interval } \\
\hline & & & & & Lower Bound & Upper Bound \\
\hline \multirow{3}{*}{ Economic well-being } & Low Rank & 716 & 3.21 & 0.69 & 3.16 & 3.26 \\
\hline & Middle Rank & 360 & 3.47 & 0.62 & 3.41 & 3.54 \\
\hline & High Rank & 125 & 3.52 & 0.74 & 3.39 & 3.65 \\
\hline \multirow{3}{*}{ Employee well-being } & Low Rank & 716 & 2.71 & 0.67 & 2.66 & 2.76 \\
\hline & Middle Rank & 360 & 2.89 & 0.67 & 2.82 & 2.96 \\
\hline & High Rank & 125 & 2.65 & 0.70 & 2.53 & 2.78 \\
\hline \multirow{3}{*}{$\begin{array}{l}\text { Environmental } \\
\text { well-being }\end{array}$} & Low Rank & 716 & 3.34 & 0.68 & 3.29 & 3.39 \\
\hline & Middle Rank & 360 & 3.42 & 0.66 & 3.35 & 3.48 \\
\hline & High Rank & 125 & 3.51 & 0.74 & 3.37 & 3.64 \\
\hline \multirow{3}{*}{$\begin{array}{l}\text { Education } \\
\text { well-being }\end{array}$} & Low Rank & 716 & 3.43 & 0.58 & 3.39 & 3.47 \\
\hline & Middle Rank & 360 & 3.60 & 0.55 & 3.54 & 3.66 \\
\hline & High Rank & 125 & 3.62 & 0.50 & 3.53 & 3.71 \\
\hline \multirow{3}{*}{$\begin{array}{l}\text { General physical } \\
\text { well-being }\end{array}$} & Low Rank & 716 & 3.82 & 0.52 & 3.78 & 3.86 \\
\hline & Middle Rank & 360 & 3.73 & 0.50 & 3.68 & 3.79 \\
\hline & High Rank & 125 & 3.94 & 0.43 & 3.86 & 4.01 \\
\hline \multirow{3}{*}{ Political well-being } & Low Rank & 716 & 3.57 & 0.71 & 3.52 & 3.62 \\
\hline & Middle Rank & 360 & 3.77 & 0.64 & 3.70 & 3.83 \\
\hline & High Rank & 125 & 3.58 & 0.80 & 3.44 & 3.72 \\
\hline \multirow{3}{*}{ Public safety } & Low Rank & 716 & 3.31 & 0.56 & 3.27 & 3.35 \\
\hline & Middle Rank & 360 & 3.50 & 0.56 & 3.45 & 3.56 \\
\hline & High Rank & 125 & 3.47 & 0.67 & 3.35 & 3.59 \\
\hline \multirow{3}{*}{ Spiritual well-being } & Low Rank & 716 & 3.62 & 0.63 & 3.58 & 3.67 \\
\hline & Middle Rank & 360 & 3.76 & 0.61 & 3.69 & 3.82 \\
\hline & High Rank & 125 & 3.75 & 0.70 & 3.62 & 3.87 \\
\hline
\end{tabular}




\section{Discussion}

The findings of this study indicate that in general Police officers obtain a mean score of $34.69(\mathrm{SD}=4.41)$ in the overall well-being assessment and their scores were associated with their ranks. That is, those in higher ranks exhibited significantly more positive well-being that those in lower ranks.

Most of low rank officers do not own their homes, perhaps because low rank officers received a very low income and unsatisfactory financial incentives and have no financial security. Thus, low rank officers and their families live in precarious conditions; have poor life style and low financial security in comparison to both middle and high rank officers.

Furthermore, in terms of the subjective well-being, in comparison to middle and high rank officers, low rank officer have less opportunities for continuing education and career development; more negative general physical well-being, lower level of self-awareness and a more negative personal identity; and are less satisfied with the government and its politics and with their family safety in their families. The results also indicated that middle and low rank officers faced poor work environment, deficient financial and economic security, lack of opportunity for continuing education and career, poor overall physical health, negative political and spiritual well-being.

In Malaysia, police officers not only are exposed to an array of work related risks; but they also live under constant apprehension of physical danger, work long and irregular hours, and faced family-work conflict due to demanding expectations at work. Thus, the health of the police officers is jeopardized and can potentially impair their work performance and the well-being of the community they served. Therefore, government and police organization must join efforts to support police officer and address those factors that impact negatively upon officers' well-being. These efforts should focus on providing better housing schemes and healthcare services and monitoring; and improving the salary and financial incentives for police officers.

\section{Acknowledgments}

The authors gratefully acknowledge the support received from Yayasan Pengaman Malaysia

\section{Reference}

(2004). Asian-Pacific Newsletter on Occupational Health and Safety, 11, 48-50. Retrieved from http://www.ttl.fi/en/publications/electronic_journals/asian_pacific_newsletter/archives/Documents/asian_pa cific_news3_2004.pdf

Anshel, M. H. (2000). A conceptual model and implications for coping with stressful events in police work. Criminal Justice and Behavior, 27(3), 375-400. Retrieved from http://cjb.sagepub.com/content/27/3/375. full.pdf

Bakker, A. B., \& Heuven, E. (2006). Emotional dissonance, burnout, and in-role performance among nurses and police officers. International Journal of Stress Management, 13(3), 423-440. Retrieved from http://psycnet.apa.org/journals/str/13/4/423/

Campbell, A., Converse, P. E., \& Rodgers, W. L. (1976). The perceived quality of life and its implications. In A. Campbell, P. E. Converse, \& W. L. Rodgers (Eds.), The quality of American life (pp. 471-508). New York: Russell Sage Foundation.

Cartwright, S., \& Cooper, C. L. (2014). Towards organizational health: Stress, positive organizational behavior, and employee well-being. In Bridging Occupational, Organizational and Public Health (pp. 29-42). Springer Netherlands. Retrieved from http://link.springer.com/chapter/10.1007/978-94-007-5640-3_3

Cummins, R. A. (1997). Assessing quality of life. In R. I. Brown (Ed.), Quality of life for people with disabilities: Models research and practice (2nd ed.). Cheltenham: Stanley Thornes.

Diener, E. (2009). Subjective well-being. Behavioral Science, 37, 11-58. Retrieved from http://link.springer.com/ chapter/10.1007/978-90-481-2350-6_2

Diener, E., \& Suh, E. (1997). Measuring quality of life: Economic, social, and subjective indicators. Social indicators research, 40(1-2), 189-216. Retrieved from https://lemosandcrane.co.uk/resources/Social\% 20Indicators\%20Research\%20Measuring\%20quality\%20of\%20life.pdf

Diener, E., Diener, M., \& Diener, C. (1995). Factor predicting the subjective well-being of nations. Journal of Personality and Social Psychology, 69(5), 851-864.

Diener, E., Sapyta, J. J., \& Suh, E. M. (1998). Subjective well-being is essential to well-being. Psychological Enquiry, 9(1), 33-37. 
Doyal, L., \& Gough, I. (1991). A theory of human need. Palgrave Macmillan.

Eid, M., \& Diener, E. (2004). Global judgments of subjective well-being: Situational variability and long-term stability. Social Indicators Research, 65(3), 245-277. Retrieved from http://link.springer.com/article/10. 1023/B:SOCI.0000003801.89195.bc\#/page-1

He, N., Zhao, J., \& Archbold, C. A. (2002). Gender and police stress: The convergent and divergent impact of work environment, work-family conflict, and stress coping mechanisms of female and male police officers. Policing: An International Journal of Police Strategies \& Management, 25(4), 687-708. Retrieved from http://www.emeraldinsight.com/doi/full/10.1108/13639510210450631

Hoque, Z., Arends, S., \& Alexander, R. (2004). Policing the police service: A case study of the rise of "new public management" within an Australian police service. Accounting, Auditing \& Accountability Journal, 17(1), 59-84. Retrieved from http://www.emeraldinsight.com/doi/full/10.1108/09513570410525210

Hussin, R. (2014). Work-family conflict and well-being among employed women in Malaysia: The roles of coping and work-family facilitation (Doctoral dissertation, University of Waikato). Retrieved from http://researchcommons.waikato.ac.nz/bitstream/handle/10289/8840/thesis.pdf?sequence $=3 \mathrm{~m}$

Lucas, R. E., Diener, E., \& Suh, E. M. (1996). Discriminant validity of well-being measures. Journal of Personality and Social Psychology, 71(3), 616-628. Retrieved from http://psycnet.apa.org/journals/psp/71/ $3 / 616 /$

Mitchell, J. T., \& Resnik, H. L. P. (1981). Emergency Response to Crisis: A Crisis Intervention Guidebook for Emergency Service Personnel. Bowie, Md.: R.J. Brady. ISBN: 0876198280, 9780876198285

Moad, S. C. (2011). Critical Incidents: Responding to Police Officer Trauma. Retrieved from http://www.cji.edu/site/assets/files/1921/chrismoad.pdf

Mokhtar, N., Husniyah, A. R., Sabri, M. F., \& Talib, M. A. (2015). Financial Well-Being among Public Employees in Malaysia: A Preliminary Study. Asian Social Science, 11(18), 49. Retrieved from http://www.ccsenet.org/journal/index.php/ass/article/download/42543/26800

Noor, N. M., Gandhi, A. D., Ishak, I., \& Wok, S. (2014). Development of indicators for family well-being in Malaysia. Social indicators research, 115(1), 279-318.

Sen, A. (1982). Choice, welfare and measurement. Oxford: Blackwell.

Sparks, K., Faragher, B., \& Cooper, C. L. (2001). Well-being and occupational health in the 21 st century workplace. Journal of occupational and organizational psychology, 74(4), 489-509. Retrieved from http://citeseerx.ist.psu.edu/viewdoc/download?doi=10.1.1.91.440\&rep=rep1\&type=pdf

Veenhoven, R. (1984). Conditions of happiness. Dodrecht: D. Reidel Publishing

Veenhoven, R. (2007). Subjective measures of well-Being. In Mc Gillvray (Ed.), Human Well-being, Concepts and Measurement (pp. 214-239), New Hampshire: Palgrave/McMillan.

Wright, R., Powell, M. B., \& Ridge, D. (2006). Child abuse investigation: An in-depth analysis of how police officers perceive and cope with daily work challenges. Policing: an international journal of police strategies \& management, 29(3), 498-512. Retrieved from http://www.emeraldinsight.com/doi/abs/10.1108/ 13639510610684728

Wright, T. A., \& Huang, C. C. (2012). The many benefits of employee well-being in organizational research. Journal of Organizational Behavior, 33(8), 1188-1192. Retrieved from http://www.readcube.com/articles/ 10.1002\%2Fjob.1828?r3_referer=wol\&tracking_action=preview_click\&show_checkout=1\&purchase_refer rer=onlinelibrary.wiley.com\&purchase_site_license=LICENSE_DENIED

Yassin Sulaiman, M., Samah, A. A., D'Silva, J. L., Shaffril, H. A. M., \& Sahharon, H. (2015). Well-Being Revisited: A Malaysian Perspective Yayasan Basmi Kemiskinan and Universiti Putra Malaysia, Shah Alam

\section{Copyrights}

Copyright for this article is retained by the author(s), with first publication rights granted to the journal.

This is an open-access article distributed under the terms and conditions of the Creative Commons Attribution license (http://creativecommons.org/licenses/by/3.0/). 